\section{Acute-on-chronic liver failure (ACLF) precipitated by severe alcoholic hepatitis: another collateral damage of the COVID-19 pandemic?}

We have read with interest the study recently published by Bajaj and colleagues. ${ }^{1}$ The authors convincingly demonstrate that underlying cirrhosis should be considered a high-risk comorbid condition among patients with COVID-19. However, increasing evidence demonstrates that patients not infected with SARS-CoV-2 are also highly affected by pandemic-related circumstances. While the COVID-19 pandemic led to a significant drop in medical emergencies with low priority presenting to emergency departments, ${ }^{2}$ presentations of medical emergencies requiring urgent treatment appeared to be significantly delayed. For example, De Rosa $e t a l^{3}$ observed a reduction of nearly $50 \%$ in admissions for acute myocardial infarctions, but the case fatality rate and associated complications were substantially increased. In addition, several studies report an increase of psychological symptoms, such as anxiety, fear and stress, during the pandemic, which correlated significantly to a general increase in alcohol consumption. ${ }^{4-6}$ Another study could show that alcohol consumption of heavy drinkers significantly increased. ${ }^{7}$ Alcohol consumption is the main trigger of acuteon-chronic liver failure (ACLF), ${ }^{8}$ which is a frequent syndrome in patients with underlying liver cirrhosis and is characterised by acute decompensation of cirrhosis, organ failure(s) and high short-term mortality. ${ }^{9}$ We retrospectively analysed the prevalence and outcome of patients with ACLF precipitated by severe alcoholic hepatitis in a non-COVID-19 intensive care unit (ICU) of the University Liver Center in Frankfurt am Main (Hesse, Germany) during the SARS-CoV-2 pandemic in 2020 in comparison with equivalent time periods between 2017 and 2019. All patients admitted to the ICU were screened for ACLF, according to the European Association for the Study of the Liver - Chronic Liver Failure (EASL-CLIF) criteria, ${ }^{10}$ via patient charts. Diagnosis of liver cirrhosis was based on clinical data, laboratory results, sonography and/or other imaging, liver biopsies and endoscopy. Patients with ACLF were categorised into two groups: (1) precipitated by severe alcoholic hepatitis and (2) precipitated by other causes.
Table 1 Patient characteristics

\begin{tabular}{|c|c|c|c|c|}
\hline Parameter & All patients & $\begin{array}{l}\text { ACLF precipitated by } \\
\text { other causes }\end{array}$ & $\begin{array}{l}\text { ACLF precipitated by severe } \\
\text { alcoholic hepatitis }\end{array}$ & $P$ value \\
\hline \multicolumn{5}{|l|}{ Epidemiology } \\
\hline Patients, n (\%) & 237 & $155(65.4)$ & $82(34.6)$ & \\
\hline Gender, male/female (\%) & $156(65.8) / 81(34.2)$ & $105(67.7) / 50(32.3)$ & $51(62.2) / 31(37.8)$ & 0.392 \\
\hline Age, median, range & $58(30-85)$ & $61(30-85)$ & $52(30-69)$ & 0.011 \\
\hline Patients who died, $\mathrm{n}(\%)$ & $169(71.3)$ & $112(72.3)$ & $57(69.5)$ & 0.654 \\
\hline Follow-up days, median, range & $17(0-1501)$ & $18(0-1501)$ & $15(0-1137)$ & 0.695 \\
\hline Aetiology of liver disease, $n(\%)$ & & & & $<0.001$ \\
\hline Alcohol abuse & $142(59.9)$ & $64(41.3)$ & $78(95.1)$ & \\
\hline Viral hepatitis & 44 (18.6) & $40(25.8)$ & $4(4.9)$ & \\
\hline NASH & $20(8.4)$ & $20(12.9)$ & - & \\
\hline Others & $31(13.1)$ & $31(20.0)$ & - & \\
\hline Transplanted patients, n (\%) & $12(5.1)$ & $12(7.7)$ & - & 0.009 \\
\hline $\begin{array}{l}\text { MELD score at admission, median, } \\
\text { range }\end{array}$ & $25(7-40)$ & $25(7-40)$ & $27(9-40)$ & 0.389 \\
\hline $\begin{array}{l}\text { Lactate at admission }(\mathrm{mg} / \mathrm{dL}) \text {, median, } \\
\text { range }\end{array}$ & $30(5-259)$ & $29(5-164)$ & $32(7-259)$ & 0.2 \\
\hline Dialysis during ICU stay, n (\%) & $117(49.4)$ & $75(48.4)$ & $42(51.2)$ & 0.682 \\
\hline $\begin{array}{l}\text { Mechanical ventilation during ICU } \\
\text { stay, } \mathrm{n}(\%)\end{array}$ & $180(75.9)$ & $115(74.2)$ & $65(79.3)$ & 0.418 \\
\hline ACLF grade, $n(\%)$ & & & & 0.052 \\
\hline 1 & $51(21.5)$ & $35(22.6)$ & $16(19.5)$ & \\
\hline 2 & $86(36.3)$ & $64(41.3)$ & $22(26.8)$ & \\
\hline 3 & $100(42.2)$ & $56(36.1)$ & $44(53.7)$ & \\
\hline \multicolumn{2}{|l|}{ Year of admission to ICU, $\mathrm{n}$ (\% all) patients } & & & $<0.001$ \\
\hline 2017 & 59 & $43(72.9)$ & $16(27.1)$ & \\
\hline 2018 & 49 & $37(75.5)$ & $12(24.5)$ & \\
\hline 2019 & 61 & $46(75.4)$ & $15(24.6)$ & \\
\hline 2020 & 68 & $29(42.6)$ & $39(57.4)$ & \\
\hline
\end{tabular}

Bold p-values are considered significant.

ACLF, acute-on-chronic liver failure; ICU, intensive care unit; MELD, Model for End-Stage Liver Disease; NASH, non-alcoholic steatohepatitis.

Severe alcoholic hepatitis was diagnosed as recently described. $^{8}$

Overall, 3649 admissions to ICU were screened during 2017-2020. Of these, 820 were admitted for a gastroenterological or hepatological disease and 237 patients presented with ACLF. In our

analysis, a moderate increase in all ACLF cases was observed in 2020 in comparison with 2017-2019 (15.9\% of all ICU cases in 2020 vs $12.2 \%-13 \%$ in $2017-2019$, respectively). The majority of patients suffered from ACLF grade 2 and 3, and the median Model for End-Stage Liver
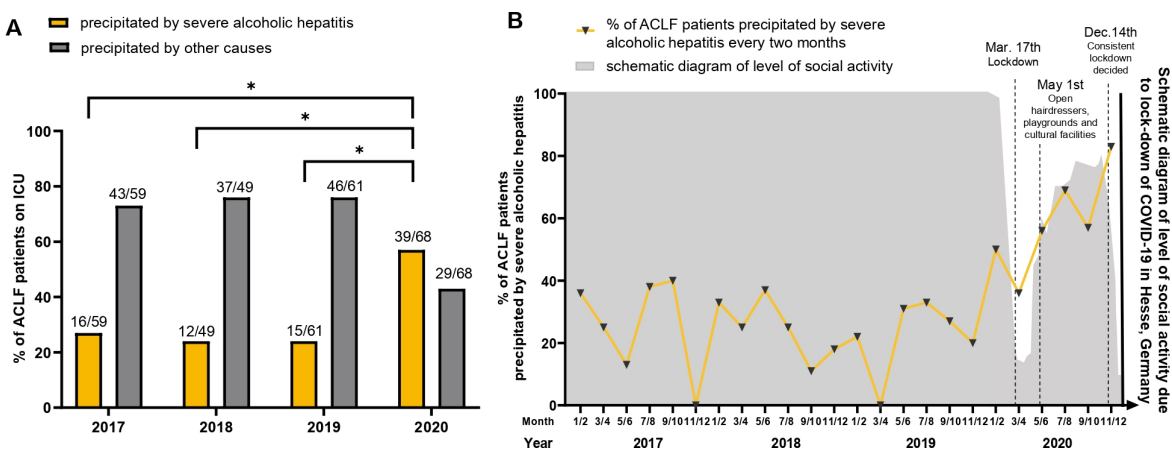

Figure 1 Increase of ACLF precipitated by severe alcoholic hepatitis during the COVID-19 pandemic. (A) Percentage of patients with ACLF precipitated by severe alcoholic hepatitis (orange) or other causes (grey) in years 2017-2020. ANOVA was performed to determine statistical significance $\left({ }^{*} p<0.05\right)$. (B) Percentage of patients with ACLF precipitated by severe alcoholic hepatitis every 2 months on a timeline in years 2017-2020 in the context of social activity level and regulations by the German government. Data on social activity were taken from the official website of the Hesse government (https://www.hessen.de/fuer-buerger/corona-hessen/interviewsreden-und-mehr/corona-massnahmen-der-landesregierung). ACLF, acute-on-chronic liver failure; ANOVA, analysis of variance; ICU, intensive care unit. 
Disease (MELD) score was 25 (table 1). Importantly, in 2020, 57\% of ACLF cases were precipitated by alcoholic hepatitis vs 24\%-27\% in 2017-2019, an increase of 111\%-137\% (figure 1A). This increase was even more pronounced over time during the pandemic and inversely correlated with reduced social activity due to pandemic-related government regulations (figure 1B). The group of patients with ACLF precipitated by severe alcoholic hepatitis included a higher percentage of ACLF grade 3 patients $(53.7 \%$ vs $36.1 \%$, respectively) and a slightly higher MELD score (27 vs 25 , respectively) in comparison with patients with ACLF precipitated by other causes. However, the overall mortality rate during hospital stay was $71.3 \%$ and did not differ between the two groups $(69.5 \%$ vs $72.3 \%$ in patients with ACLF precipitated by severe alcoholic hepatitis and other causes, respectively) and the analysed time periods $(73.3 \%$ in 2017-2019 vs $66.2 \%$ in 2020). The median survival was 19 days for patients with severe alcoholic hepatitis vs 20 days for patients without, with an HR of 1.08 (95\% CI 0.79 to 1.5 ), and again 19 days in 2017-2019 vs 21 days in 2020, with an HR of 1.016 (95\% CI 0.72 to 1.44 ).

In summary, in our liver centre, the rate of ACLF precipitated by acute severe alcoholic hepatitis markedly increased during the COVID-19 pandemic, which was associated with a high mortality. The apparent relationship with pandemic-related circumstances advocates for more support for this vulnerable patient collective.

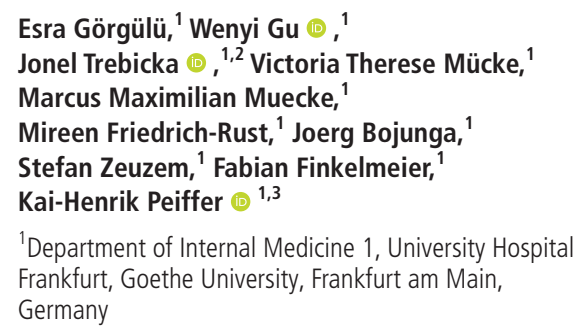

${ }^{2}$ European Foundation for the Study of Chronic Liver Failure - EF CLIF, Barcelona, Spain

${ }^{3}$ Department of Virology, Paul-Ehrlich-Institut, Langen, Germany

Correspondence to Dr Kai-Henrik Peiffer, Hospital of the Goethe University Frankfurt Department of Medicine, Gastroenterology Hepatology Pneumology Allergology Endocrinology Diabetology, Frankfurt am Main 60590, Hessen, Germany;

kai-henrik.peiffer@kgu.de

Contributors Concept and design: K-HP, FF. Acquisition of data: EG, K-HP, FF. Analysis and interpretation of data: EG, K-HP, FF, WG, JT. Drafting of the manuscript: EG, K-HP, FF, WG, JT. Critical revision of the manuscript for important intellectual content: JT, MF-R, JB, VTM, MM, SZ. Statistical analysis: EG, K-HP, $F F, W G$.

Funding The authors have not declared a specific grant for this research from any funding agency in the public, commercial or not-for-profit sectors.

Competing interests None declared.

Patient and public involvement Patients and/or the public were not involved in the design, or conduct, or reporting, or dissemination plans of this research.

Patient consent for publication Not required.

Provenance and peer review Not commissioned; internally peer reviewed.

\section{(0) \\ OPEN ACCESS}

Open access This is an open access article distributed in accordance with the Creative Commons Attribution Non Commercial (CC BY-NC 4.0) license, which permits others to distribute, remix, adapt, build upon this work non-commercially, and license their derivative works on different terms, provided the original work is properly cited, appropriate credit is given, any changes made indicated, and the use is non-commercial. See: http:// creativecommons.org/licenses/by-nc/4.0/.

(c) Author(s) (or their employer(s)) 2021. Re-use permitted under CC BY-NC. No commercial re-use. See rights and permissions. Published by BMJ.

FF and K-HP contributed equally.

$$
\text { A Check for updates }
$$

To cite Görgülü E, Gu W, Trebicka J, et al. Gut Epub ahead of print: [please include Day Month Year]. doi:10.1136/gutjpl-2021-325278
Received 29 May 2021

Accepted 9 June 2021

Gut 2021;0:1-2. doi:10.1136/gutjnl-2021-325278

\section{ORCID iDs}

Wenyi Gu http://orcid.org/0000-0002-1615-6064 Jonel Trebicka http://orcid.org/0000-0002-7028-3881 Kai-Henrik Peiffer http://orcid.org/0000-0002-37574476

\section{REFERENCES}

1 Bajaj JS, Garcia-Tsao G, Biggins SW, et al. Comparison of mortality risk in patients with cirrhosis and COVID-19 compared with patients with cirrhosis alone and COVID-19 alone: multicentre matched cohort. Gut 2021;70:531-6.

2 Slagman A, Behringer W, Greiner F, et al. Medical emergencies during the COVID-19 pandemic. Dtsch Arztebl Int 2020;117:545-52.

3 De Rosa S, Spaccarotella C, Basso C, et al. Reduction of hospitalizations for myocardial infarction in Italy in the COVID-19 era. Eur Heart J 2020;41:2083-8.

4 Mazzarella C, Spina A, Dallio M, et al. The analysis of alcohol consumption during the severe acute respiratory syndrome coronavirus 2 Italian lockdown. Minerva Med 2021. doi:10.23736/500264806.21.07354-7. [Epub ahead of print: 05 May 2021].

5 Gasteiger N, Vedhara K, Massey A, et al. Depression, anxiety and stress during the COVID-19 pandemic: results from a new Zealand cohort study on mental well-being. BMJ Open 2021;11:e045325.

6 Killgore WDS, Cloonan SA, Taylor EC, et al. Mental health during the first weeks of the COVID-19 pandemic in the United States. Front Psychiatry 2021;12:561898.

7 Rossow I, Bye EK, Moan IS, et al. Changes in alcohol consumption during the COVID-19 PandemicSmall change in total consumption, but increase in proportion of heavy drinkers. Int J Environ Res Public Health 2021;18. doi:10.3390/ijerph18084231. [Epub ahead of print: 16 Apr 2021].

8 Trebicka J, Fernandez J, Papp M, et al. Predict identifies precipitating events associated with the clinical course of acutely decompensated cirrhosis. J Hepatol 2021;74:1097-108.

9 Mezzano G, Juanola A, Cardenas A, et al. Global burden of disease: acute-on-chronic liver failure, a systematic review and meta-analysis. Gut 2021. doi:10.1136/gutjnl-2020-322161. [Epub ahead of print: 12 Jan 2021].

10 Moreau R, Jalan R, Gines P, et al. Acute-On-Chronic liver failure is a distinct syndrome that develops in patients with acute decompensation of cirrhosis. Gastroenterology 2013;144:1426-37. 